\title{
MAKING EXTRACTIVE INVESTMENTS WORK FOR AFRICA'S DEVELOPMENT: WHAT ROLE FOR QATAR IN SHAPING THE DEBATE ON NATURAL RESOURCE GOVERNANCE?
}

\author{
Fantu Cheru*
}

\begin{abstract}
At present, emerging economies such as China, are the major importers as well as investors in Africa's extractive sector. Indeed, they maintain a "stranglehold" on the continent regarding finance for development. Their success in gaining access to the resources of Africa is linked to an effective strategy that combines trade inducements, increased investment flows, aid for infrastructure and construction and technology transfers. With the recent dramatic decline in the price of commodities, and China's re-balancing with greater emphasis on consumption-driven growth model, growth prospects in commodity-dependent Africa has dampened. Qatar, with its abundant hydrocarbon reserves and US $\$ 10$ billion foreign exchange reserves, deploys its "soft power" to enable African countries develop their extractive sector fully, industrialize and end China's financial stranglehold on the continent. Qatar can help develop Africa's mineral processing industries through public private partnerships and experience. This is because of Qatar's track record as a sound manager of natural resources. This type of partnership will assist African countries to get more out of their natural resources through valueaddition, and further deepen domestic technological capacity and job creation.
\end{abstract}

Key words: Qatar, China, Africa, minerals, oil, extractive, development

DOI: https://dx.doi.org/10.4314/jsdlp.v8i1.8

\section{INTRODUCTION}

Africa is at the epicentre of the global scramble for resources. A continent endowed with many natural resources, including plentiful land and

* Professor and Senior Researcher, African Studies Center, Leiden University, the Netherlands Associate Senior Fellow, Stockholm International Peace Research Institute (SIPRI). 
fertile soils, as well as oil and minerals. Africa has about 12 per cent of the world's oil reserves, 42 per cent of its gold, 80 to 90 per cent of chromium and platinum group metals, and 60 percent of arable land in addition to vast timber resources. ${ }^{1}$ Recent discoveries of oil and gas in Uganda, Kenya, Tanzania, Mozambique and Liberia have raised the profile of the continent, bringing to light the immense opportunities that could be derived, but also ringing alarm bells on the potential challenges this portends for poverty reduction, industrialization, and sustainable management of natural resources. ${ }^{2}$ The commodity supercycle, largely influenced by rising demand from emerging economies such as China, benefit many commodity exporting countries, allowing them to invest the windfall earnings in vital infrastructure and social services. ${ }^{3}$

With the recent dramatic decline in the price of commodities, the sustainability of commodity-based export strategy is under scrutiny. China's re-balancing with greater emphasis on consumption-driven growth has dampened economic prospects in commodity-dependent African countries. Africa needs deep structural reforms to respond to these challenges. One possibility is redirecting the continent away from commodity dependence and towards industrialization and valueaddition in commodities.

Despite impressive Gross Domestic Product growth rates over the past decade, the continent has not achieved broad-based development and structural transformation. This is due to several factors: limited institutional, legal and human capacity to develop and manage resources effectively; poor capacity to create linkages between the mineral resource sector and other sectors of the economy through beneficiation, and value-addition; and poor state capacity in contract negotiation, collecting and investing resource rents wisely and sustainably with a view to achieving structural transformation. ${ }^{4}$

1 UNECA, Economic Report on Africa 2013: Making the Most of African's Commodities (Addis Ababa, 2013), 8.

2 I. Ramdoo, "From Curse to Purse: Making Extractive Resources Work for Development" (Discussion Paper No. 136, European Centre for Development Policy Management (EPCDM, 2012).

3 Cyril Obi, "African Oil in the Energy Security Calculations of China and India". In FantuCheru and Cyril Obi (eds.), The Rise of China and India in Africa: Challenges, Opportunities and Critical Interventions (London: ZED Press 2010), pp. 181-192.

4 UNECA (n 2); P. Collier, The Plundered Continent (New York: Oxford University Press 2010). 
The aim of this article is to examine the extent to which Qatar can strategically deploy its soft power towards developing the extractive and industrial sectors in Africa. While African countries have benefited from rising commodity prices in the short-term, they exercise very little control on the management of their strategic resources. ${ }^{5}$ This is partly due to the emerging economies, the major importers as well as investors in Africa's extractive sector who maintain a stranglehold on the finance that Africa needs for development. Their success in gaining access to the resources of Africa is linked to an effective strategy that combines trade inducements, increased investment flows, aid for infrastructure and construction (mainly transportation projects to enable better delivery), and technology transfers.

Qatar, with its abundant hydrocarbon reserves and US\$10 billion foreign exchange reserves, ${ }^{6}$ can bring to end the BRICS financial stronghold on African governments, by providing alternative financing source with fewer strings attached. Qatar can take the lead in support of the development of mineral processing industries in Africa through public private partnerships, and experience sharing in terms of the management of natural resources given Qatar's track record in this respect. This type of partnership will assist African countries to get more out of their natural resources through value addition, further deepening of the domestic technological capacity and job creation.

\section{CAN QATAR FIND A NICHE IN GROWING AFRICA?}

Major transformations have been affecting Africa's international relations since the early 2000s. While the traditional links with the West remain strong, Africa is moving away from its post-colonial NorthSouth relations towards a more diverse, business-centric set of partnerships with a wide array of actors. Newly emerging economic powers from the global South have started to put their imprint on the continent in a very significant way. The changing global political landscape has provided some degree of policy space to African

5 UNECA (n 2).

6 Market Trading Info, "State of Qatar - Economic Review". < http://gulfbase.com/ Gcc/Index/6> accessed 20 May 2016. 
policymakers to articulate an authentic and transformative continental development agenda in a manner never seen before. ${ }^{7}$

Table 1: Africa and New Forms of South-South Partnership

\begin{tabular}{lll}
\hline $\begin{array}{l}\text { Partnerships with formal } \\
\text { dialogue platform }\end{array}$ & $\begin{array}{l}\text { Inter-regional forums } \\
\text { with no formal dialogue } \\
\text { platform }\end{array}$ & $\begin{array}{l}\text { Private-sector-led } \\
\text { forums }\end{array}$ \\
\hline - FOCAC (China) & $\begin{array}{l}\text { Africa-South America } \\
\text { Strategic Partnership }\end{array}$ & $\begin{array}{l}\text { Malaysia-Africa } \\
\text { Business Forum }\end{array}$ \\
& - Afro-Arab \\
- ISAF (India) & $\begin{array}{l}\text { Cooperation } \\
\text { - Korea-Africa Summit }\end{array}$ & $\begin{array}{l}\text { Africa-Singapore } \\
\text { Business Forum }\end{array}$ \\
& - Iran-Africa Summit & $\begin{array}{l}\text { Taiwan-Africa } \\
\text { Business Summit }\end{array}$ \\
Turkey-Africa & New Asian-African \\
Summit & Strategic Partnership & \\
\hline
\end{tabular}

Source: UNCTAD 2010.

The key vectors of interaction between Africa and the new development partners from the South include trade, FDI portfolio investments, and development cooperation. Each of the new partners have taken a strategic approach to deepening their relationship with Africa. They respectively bundle their aid, trade and FDI in order to achieve two important objectives - secure long-term supply of oil and other resources from Africa to fuel their growing economies; and capture a significant portion of Africa's growing market in goods and services.

\subsection{Trade}

The number of sectors in which emerging partners conduct trade varies

7 AfDB/OECD/UNDP/UNECA, African Economic Outlook 2011: Africa and Its Emerging Partners (Tunis, Paris, New York and Addis Ababa 2011); Chaturvedi, Sachin, Thomas Fues and E. Sidiropoulos (eds.), Development Cooperation and Emerging Powers: New Partners or Old Partners? (London: ZED Books 2012); UNCTAD, Economic Development in Africa 2010: South-South Cooperation, Africa and the New Forms of Development Partnership (UNCTAD: New York and Geneva 2010). 
widely: mining, energy, infrastructure, manufacturing, telecommunications, construction, agriculture, services. Europe remains Africa's largest trading partner, with Africa's trade with Asia rising by 22 per cent between 2012 and 2013, while trade with Europe grew by just 15 per cent. ${ }^{8}$ Manufactured exports from Europe to Africa fell from 32 per cent of the total in 2002 to 23 per cent in 2011. On the other hand, Asia's share in Africa's trade rose from 13 per cent of the total to 22 per cent during the same period. ${ }^{9}$ While China remains the dominant actor in Africa, the combined volume of trade by the other emerging partners such as Brazil, Korea, India, and Turkey outweighs China in importance.

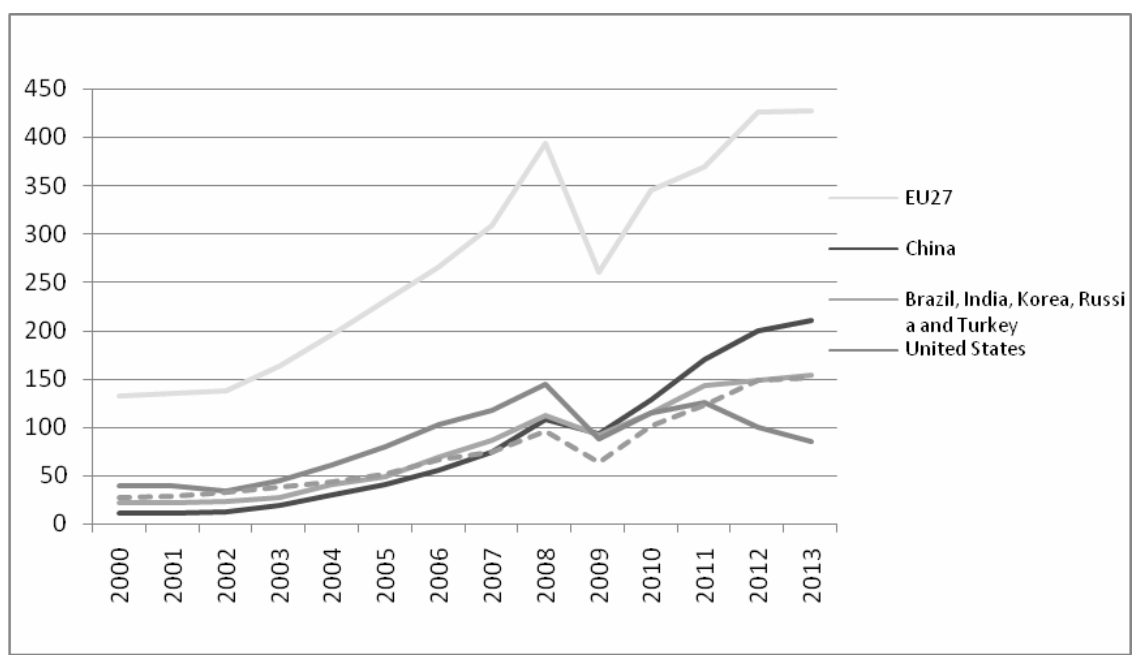

Figure 1. Africa's Trading Partners, 2000 to 2013

Source: UNCTAD (2013), Global Investment Trend Monitor, No.15 and African Economic Outlook 2015:vi, Figure 4

Notably, much of this growing trade between Africa and the emerging economies is heavily concentrated in a half dozen African countries that export minerals and petroleum. If we take China alone as an example, its top trading partners in Africa are also major exporters of minerals, precious metals, and petroleum (Figure 2). They include: South Africa, Angola, Sudan, Nigeria, Egypt, Libya, Algeria, Liberia,

8 OECD/AfDB, African Economic Outlook 2015: Regional Development and Spatial Inclusion (Paris: OECD 2015), p. vi.

9 Ibid. 
Congo and the Democratic Republic of the Congo. These products accounted for between 60 and 80 per cent of total exports, a pattern very similar to Africa's trade with its traditional partners. ${ }^{10}$ In 2013, for example, of the US $\$ 602$ billion in African exports, oil-exporting African countries exported US\$330 billion, while South African exports amounted to US\$96 billion. ${ }^{11}$ On the other hand, African imports from emerging economies are dominated by manufactured goods, industrial products, and consumer goods - a pattern reminiscent of the old colonial division of labour. With few exceptions, Africa does not consume or add significant value to its exports in minerals and commodities. The continent remains a net exporter of raw materials that fuel prosperity and development in other regions. ${ }^{12}$

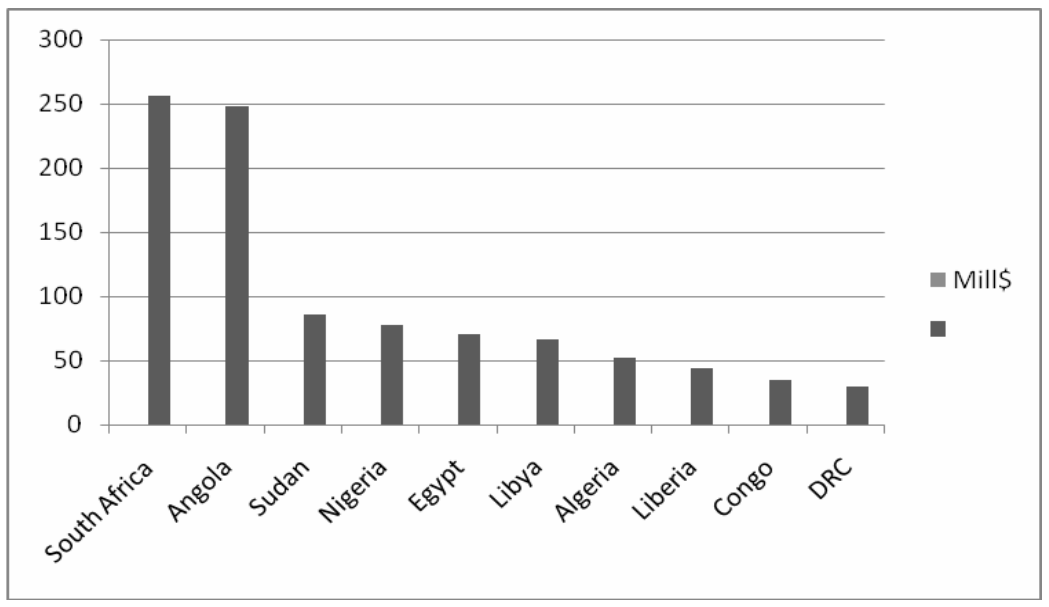

Figure 2. Trade between China and Top Ten African Countries Measured in US\$ millions, 2010

Source: Peoples Republic of China, China-Africa Trade an Economic Relationship, annual Report 2011:3.

Given its vulnerability to global shocks, it is imperative that Africa embarks on a path of diversification, industrialization and value

10 UNCTAD. 2013. Global Investment Trend Monitor, No. 15 and African Economic Outlook, 2015, Figure 4.

11 AEO. 2015. African Economic Outlook 2015, p. vi.

12 UNECA (n 2). 
addition. ${ }^{13}$ Ethiopia provides an excellent example. Its inexpensive yet relatively skilled labour force, coupled with the government's proactive policy to court Chinese and Turkish investors as well as its continued investment in vital infrastructure to reduce transaction cost for investors, have transformed Ethiopia into an idle investment destination for Chinese investors who cannot keep up with high labour cost in China. ${ }^{14}$ The rebalancing underway in China is the result of urbanization and globalization that is transforming economic geography in a proud way. Countries that have an effective national development planning capacity and are able to read in advance the emerging threats and opportunities in the world economy are more likely to benefit from increased urbanization and globalization.

\subsection{Special Economic Zones (SEZ's)}

China is no newcomer to investment in special economic zones (SEZ), particularly in Africa. According to Rasagam et al, China's incentive for investment in SEZs appears to be anchored in its burgeoning trade with Africa, both in the import of manufactured goods by African states and the export of raw materials and natural resources. SEZs are seen as potential logistics and production platforms for Chinese companies to further penetrate continental, regional, and national markets. They benefit Africans by moving some manufacturing and processing activities from China to these zones, thereby increasing the value addition of African natural resources and agricultural outputs. ${ }^{15}$ Moreover, the sustained increase of labour costs in China could create the opportunity for Africa's expanding labour force to engage in manufacturing activities, thereby diversifying the continent's specialization pattern. Some economists also believe that with the establishment of a continental free trade area, Chinese-Africa trade may well experience dramatic and exponential growth.

\subsection{Foreign Direct Investment (FDI)}

Africa continues to attract private capital because of its improved

13 Ibid.

14 Fantu Cheru, "Emerging Southern Powers and new forms of South-South Cooperation: Ethiopia's Strategic Engagement with China and India", Third World Quarterly (2016) 37 (4), pp. 592-610.

15 D. Brautigam and T.Xiaoyang, "African Schenzhen: China's Special Economic Zones in Africa" (2011) 49, Journal of Modern African Studies, pp. 27-53. 
business environment. FDI is a large external source of finance but was surpassed in 2010 by remittances, which also are the most stable source of external financing. Its FDI which increased fromUS $\$ 56.6$ billion in 2013 to US $\$ 61.1$ billion in 2014 further increased to US $\$ 66.9$ billion in 2015, an equivalent of 4.1 percent of GDP. Portfolio flows, on the other hand, decreased from US $\$ 31.6$ billion in 2013 to US $\$ 24.1$ billion in 2014 because of volatile global monetary and political situations. ${ }^{16}$ Despite the slow recovery in developed and emerging economies, both FDI and portfolio equity flows are expected to continue increasing, underscoring the global private sector's appetite for the continent's opportunities.

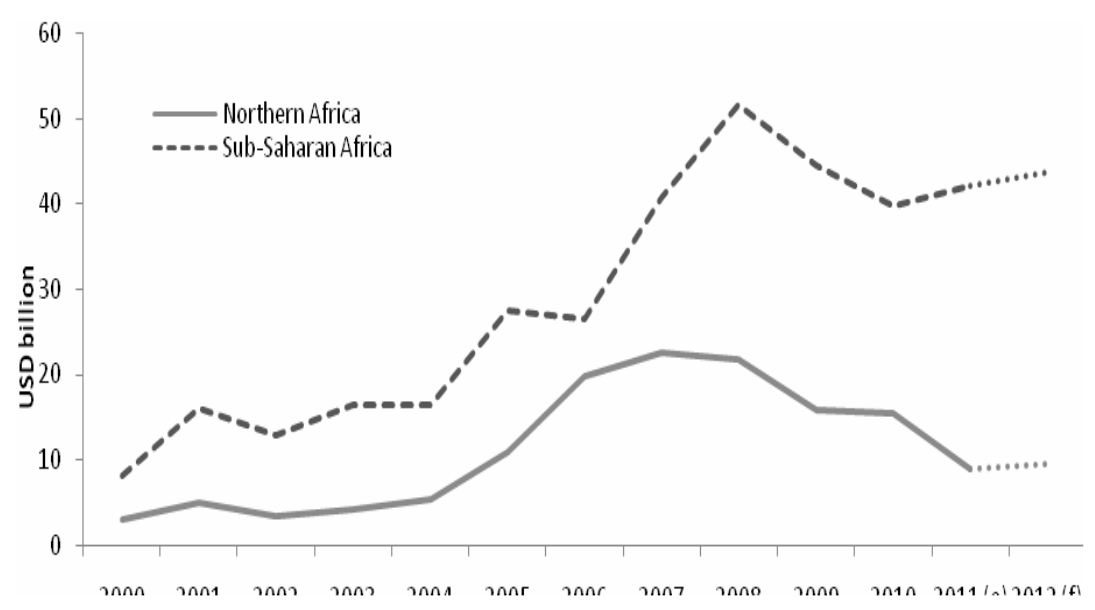

Figure 3. Foreign Direct Investment to Africa, 2000-2013

Source: OECD/AfDB, African Economic Outlook 2014:53, Figure 2.5

It is important to note that FDI inflows continue to be unevenly distributed with a large share going to the extractive sector in a limited number of African countries. ${ }^{17}$ In 2013, for example, resource-rich

16 UNECA, "Economic Report on Africa 2015: Industrializing through Trade", 24, Figure 1.16); OECD/AfDB, African Economic Outlook 2014: Global Value Chains and Africa's Industrialization (Paris: OECD, 2014), pp. 48-53.

17 H. Edinger and C. Pstorius, "Aspects of Chinese Investments in the African Resources Sector" (2011) 111, The Journal of the Southern African Institute of Mining and Metallurgy. 
countries accounted for 95 per cent of the increase in FDI to Africa, driven by a surge of US $\$ 1.8$ billion ( +39 per cent) in inflows to South Africa. The top six recipients, representing one third of the continent's population, received the same amount of FDI as the remaining 48 countries put together. The largest recipients were South Africa and Nigeria, with an estimated US $\$ 6.4$ billion and US $\$ 6.3$ billion, respectively. Mozambique (US\$ 4.7 billion), Morocco (US\$ 4.3 billion), Ghana (US\$ 3.3 billion), and Sudan (US\$ 2.9 billion) close the list. ${ }^{18}$

The share of the BRICS in Africa's total FDI stock rose from 8 per cent in 2009 to 12 per cent in 2012, amounting to US\$ 67.7 billion. ${ }^{19}$ Excluding the OECD countries, China held the largest stock of FDI in Africa, estimated at US\$ 27.7 billion; followed by South Africa and Malaysia with US\$ 22.9 and US\$ 15.8 billion, respectively (IMF 2014). This said, Africa remains a comparatively minor destination for Chinese outward foreign direct investment (OFDI). In 2012, for example, Africa accounted for 4.1 per cent (US\$ 21.73 billion) of total Chinese OFDI stock. ${ }^{20}$

Finally, it is important to recognize that the actual volume of FDI to Africa from emerging economies is understimated by a large margin given a broad variety of financing mechanisms that these countries provide to Africa to finance development. For example, investments by private entities from emerging economies are most likely registered as FDI, whereas deals involving state-owned enterprises often involve a range of financing and are not counted as FDI. Export credits may be registered as aid, when in fact they may be financing investment in particular sectors.

\subsection{Aid and Technical Assistance}

Aid and technical assistance to Africa from the emerging partners has also been increasing in recent years. Observably, the composition of aid and the mode of delivery is different from the one practised by the traditional western donors. It usually consists of concessional loans; buyers and export credit; and resource-for-infrastructure deals. ${ }^{21}$

18 IMF, Regional Economic Outlook: Sub-Saharan Africa 2013 (Washington, DC: International Monetary Fund 2013).

19 IMF, Coordinated Investment Survey 2014. < http;//data.imf.org/CDIS >

20 UNCTAD, World Investment Report 2015 (Geneva: UNCTAD 2015).

21 D. Brautigam, "Aid with Chinese Characteristics: Chinese Foreign Aid and Development Finance Meets OECD-DAC Aid Regime" (2001) 23 (5) Journal of International Development, pp. 752-764. 
First, unlike the traditional donors, emerging partners provide more support in the form of concessional loans rather than grants. Second, a large proportion of support from these countries comes in the form of technical assistance tied to project support. Third, emerging partners tend to provide support to the infrastructure and productive sectors while traditional partners target the social sector and broad macroeconomic and sectoral reforms.

What is clear is that, unlike the traditional western donors, emerging partners from the South exercise a much closer strategic integration of aid, trade, and FDI to achieve their national interests. ${ }^{22}$ Despite the rhetoric of non-interference and no-conditionality, these new partners impose non-policy conditions, such as access to natural resources or the purchase of goods and services in exchange for money and investment promised at the conclusion of the various summits. Angola, Sudan and the Democratic Republic of the Congo (DRC) are three countries where such unfavourable donor practices have been used extensively. ${ }^{23}$ Therefore, transforming these unfavourable donor practices is a precondition for establishing a transparent legal, institutional, and governance regime that will allow sustainable management of Africa's natural resources. Qatar can certainly play the role of an honest broker by throwing itself into the mix and by strategically using its soft power.

\section{ALIGNING QATAR'S SOFT POWER WITH AFRICA'S LONG-TERM PRIORITIES}

Joseph Nye defines soft power as "the ability to affect others to obtain the outcomes one wants through attraction rather than coercion or payment". ${ }^{24}$ Nye notes that one can affect the of behaviour of others in three ways - through threats of coercion (stick); inducements (carrots); and attractions based on principles or values that others want to emulate (democratic values).

As a small country heavily dependent on the export of petroleum to world markets, Qatar has been successful in building up a vibrant

22 UNCTAD (n 8) 45.

23 Cyril Obi (n 4),pp. 181-192.

24 Joseph Nye, "Public Diplomacy and Soft Power" (2008) 616 The Annals of the American Academy of Political and Social Science, 94. 
Table 2. Selected Features of Support by Development Partners

\begin{tabular}{|c|c|c|c|c|}
\hline DAC Donors & Mostly Grants & $\begin{array}{l}\text { Policy \& Non- } \\
\text { Policy } \\
\text { Conditions }\end{array}$ & $\begin{array}{l}\text { Away From } \\
\text { Project-- } \\
\text { Towards } \\
\text { Budget } \\
\text { Support }\end{array}$ & $\begin{array}{l}\text { Peer } \\
\text { Reviewed by } \\
\text { Other } \\
\text { Donors } \\
\text { Review) }\end{array}$ \\
\hline China & $\begin{array}{l}\text { Grants and } \\
\text { concessional } \\
\text { loans }\end{array}$ & $\begin{array}{l}\text { Non-policy } \\
\text { conditions }\end{array}$ & Project & FOCAC \\
\hline India & $\begin{array}{l}\text { Grant and } \\
\text { concessional } \\
\text { loans }\end{array}$ & $\begin{array}{l}\text { Non-policy } \\
\text { conditions }\end{array}$ & Project & $\begin{array}{l}\text { India-Africa } \\
\text { Summit }\end{array}$ \\
\hline Brazil & $\begin{array}{l}\text { Co-financing } \\
\text { through } \\
\text { triangular } \\
\text { cooperation }\end{array}$ & $\begin{array}{l}\text { Non-policy } \\
\text { conditions }\end{array}$ & Project & $\begin{array}{l}\text { No platform, } \\
\text { except for } \\
\text { IBSA }\end{array}$ \\
\hline Turkey & Grants & & Project & $\begin{array}{l}\text { Turkey- } \\
\text { Africa } \\
\text { Summit }\end{array}$ \\
\hline S. Korea & $\begin{array}{l}\text { Grants and } \\
\text { loans }\end{array}$ & $\begin{array}{l}\text { Non-policy } \\
\text { conditions }\end{array}$ & Project & $\begin{array}{l}\text { Korea-Africa } \\
\text { Summit }\end{array}$ \\
\hline $\begin{array}{l}\text { Arab } \\
\text { Countries }\end{array}$ & $\begin{array}{l}\text { Grants and } \\
\text { loans }\end{array}$ & & Project & \\
\hline
\end{tabular}

Source: UNCTAD, Economic Development in Africa 2010, Table 10.

economy, enviable in the Arab world. It has used its resources strategically to become an effective foreign policy player and opinion shaper in the Middle East. The key attributes of Qatar's "soft power" include:

i. Political stability in a volatile region by virtue of its strategic military alliance with the United States.

ii. Model country image owing to its responsible management of natural resources for development and to create a more diversified economy - just like Norway.

iii. An effective income distribution policy.

iv. A generally liberal and tolerant social/cultural environment in a region where conservative Islamic values are the order of the day.

v. A generous aid policy. 
vi. Huge financial reserves that it deploy to establish an alternative development finance platform that other countries can tap into to finance major infrastructural projects. This is not only good for Africa; it is also good business for Qatar.

vii. First rate universities that can serve as a platform for research and knowledge exchange in the field of extractives development and the management of resource rents for broadbased development and industrialization.

Two of these attributes are critically important for establishing a win-win partnership between Qatar and African countries. The first deals with Qatar's successful development experience in translating its natural resource wealth into broad-based development and well diversified economy. The second has to do with Qatar's immense financial reserve and Sovereign Wealth Fund. This is a strategic resource that can place Qatar as an important player in the field of development finance that African countries can turn to.

\section{HARNESSING QATAR'S SOFT POWER TO SUPPORT AFRICA'S DEVELOPMENT PRIORITIES}

The major issue facing policy makers in Africa is the sustainability and structural transformation of the economy for the next 50 years. The high priority accorded to structural transformation has to be understood within the context of Africa's historical position in the global division of labour and the continent's recent experience with the regressive policies of donor mandated structural adjustment programmes. The call for structural transformation is, therefore, designed to end the perverse process of development described above.

To successfully embark on a structural transformation path, African leaders have developed a common vision and position on what to do to achieve Africa's structural transformation in two important strategic policy documents. These are The African Union's Agenda 2063, and the African Common Position on Post-2015 Agenda (CAP). ${ }^{25}$ Agenda 2063 is a forward-looking framework which charts Africa's development trajectory over the next 50 years. Agenda 2063 expresses seven broad

25 African Union Commission, Agenda 2063: The Africa We Want (Africa Common Position on the Post-2015 Development Agenda, Addis Ababa: African Union Commission 2014). 
aspirations that emanate from the various consultations held with stakeholders and outlines eleven strategic initiatives to fast-track its implementation. It builds on the experiences of previous plans such as the Lagos Plan of Action, the Abuja Treaty and NEPAD as well as other continental and regional plans and frameworks that are shaping the continent's transformation agenda. It delineates the roles of each stakeholder such as RECs, Member States, Civil Society, private sector and development partners.

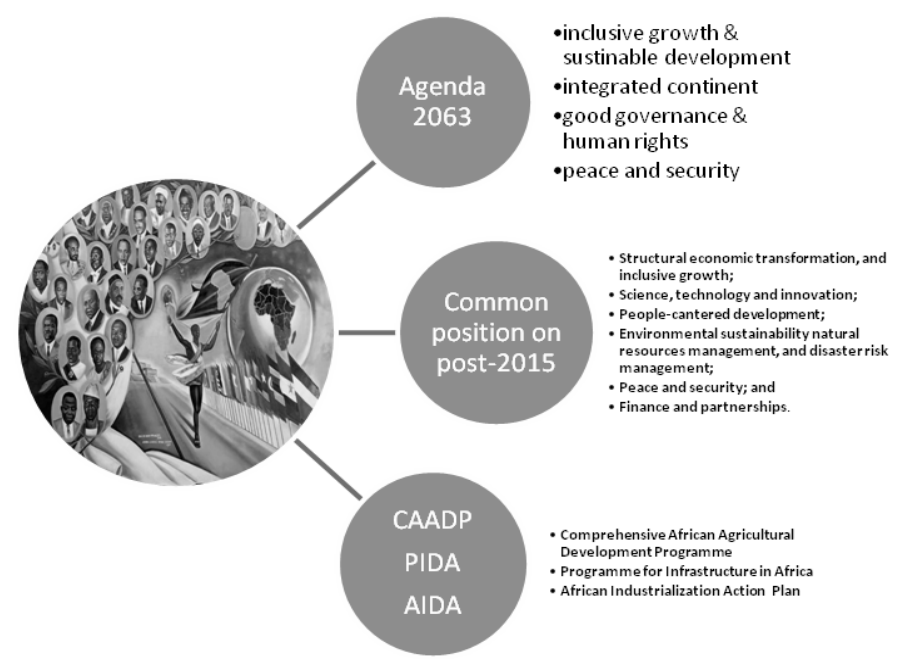

Figure 4. Africa's development architecture

Source: Compiled by the author.

The adoption of the AU Agenda 2063 coincided with the adoption of the African Common Position on the Post-2015 Development Agenda. ${ }^{26}$ The Common African Position on post-2015 Agenda groups Africa's development priorities into six pillars each with sub-themes:

i. Structural economic transformation, and inclusive growth.

ii. Science, technology and innovation.

iii. People-centered development.

iv. Environmental sustainability natural resources management, and disaster risk management.

26 AUC. 2014. African Common Position on the Post-2015 Development Agenda, (Addis Ababa: African Union). 
v. Peace and security; and

vi. Finance and partnerships.

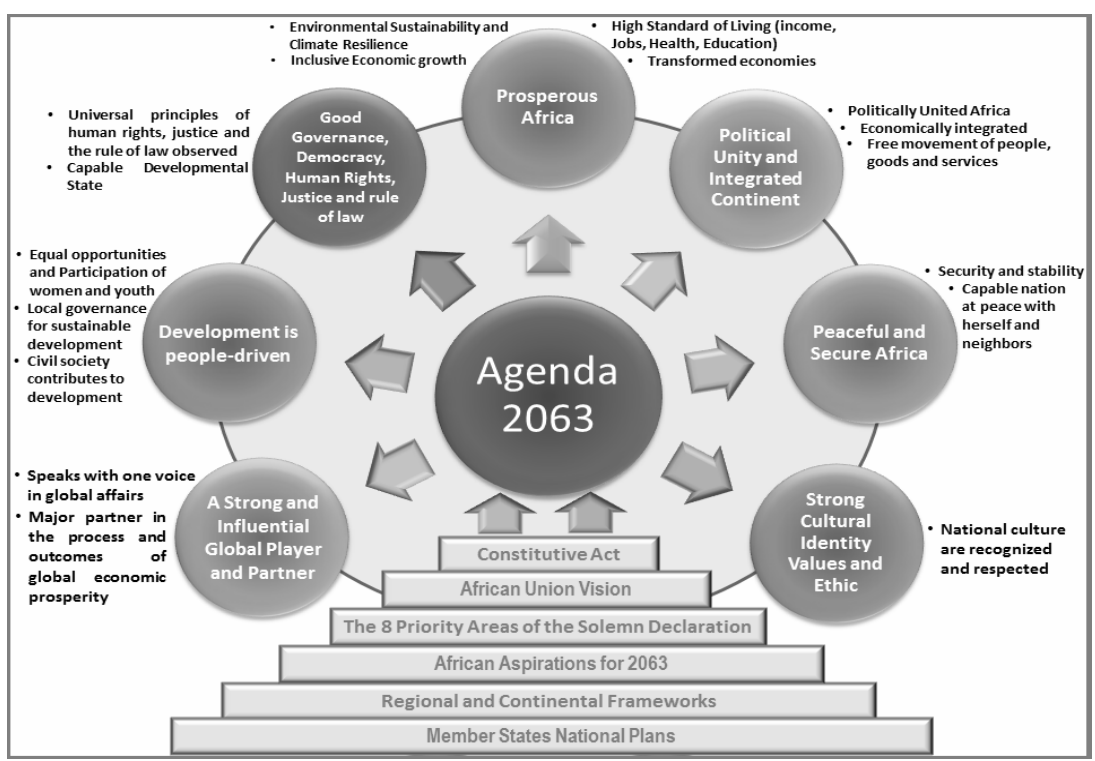

Figure 7. Key Components of Agenda 2063

The AU Agenda 2063 and the CAP both emphasize the importance of developing a productive capacity underpinned by value addition, with a particular attention paid to youth empowerment, gender equality, and a truly inclusive and transformative global partnership. The essential pillars of a transformative strategy have been spelled out in a number of strategy documents adopted by the Heads of States, such as the Comprehensive African Agricultural Development (CAADP), the Programme for Infrastructure Development in Africa (PIDA), and the African Industrial Development Action (AIDA), among others. ${ }^{27}$

27 AUC/NEPAD, Comprehensive African Agriculture Development Programme (NEPAD: Midrand, South Africa 2003); AUC, "Action Plan for the Accelerated Industrial Development of Africa" (AU Conference of Ministers of Industry, 1st Extraordinary Session, 24-27 September 2007, Midrand: South Africa); AUC, "Strategy for the Implementation of the Plan of Action for the Accelerated Industrial Development of Africa" (Conference of African Ministers of Industry, 18th Ordinary Session, Durban, South Africa, 24-28 October 2008, (AU/MIN/ CAM/3 (XVIII). 
Therefore, the Quatar-Africa Partnership must be guided by these and other Africa-owned, and Africa-led development frameworks.

\subsection{What should the Qatar-Africa Partnership Prioritize?}

The AU Agenda 2063 and the African Common Position on the post2015 Agenda have zeroed in on the key policy pillars that are necessary for achieving a structural transformation and an inclusive growth. Many of these strategic issues have been echoed in several issues of the Economic Report on Africa published by ECA since 2010. These policy pillars include:

\subsection{Leveraging Green Growth through Agriculture (value addition and processing)}

Agriculture remains central to most African economies. According to the African Development Bank, the agricultural sector in Africa employs 65-70 per cent of the workforce, and occupies a third of the continent's GDP. The continent is endowed with 60 per cent of the world's rain-fed arable land estimated at a potential of over 300 million hectares. ${ }^{28}$ Yet by 2007, the continent had become a net importer of food and agricultural products with imports exceeding exports by about US\$ 22 billion. ${ }^{29}$ The African agricultural sector is deficient in capital needed to improve farm productivity, enhance crop yields and produce more food for consumption.

Much remains to be done in boosting the productive capacity of the sector through modernization of farming, increasing crop yields, rapid investment in infrastructure (roads electricity, and water) and increasing the supply of inputs like improved seeds and fertilizer, equipment and machinery for medium and large-scale farming as well as financing services. This presents opportunities for Qatar and potential investors to partner in industrial and semi-industrial ventures such as food-processing agro-industries, that have the potential to link with global value chains, thus increasing incomes and jobs for African countries.

\subsection{Industrializing for Job Creation (value-addition)}

African exports are dominated by primary commodities, thereby limiting

28 AGRA, Africa Agriculture Status Report (Nairobi: AGRA 2013).

29 FAO, "Why Africa Has Become a Net Food Importer?" (2011). 
promising potential gains from value addition, potential employment opportunities from processing primary commodities, and finally Africa's competitiveness in global markets. At present, the continent's share in world manufacturing value addition has remained very low, standing at 1.5 per cent, down from its value of 1.9 per cent in $1980 .{ }^{30} \mathrm{~A}$ concerted effort is required on the part of African governments and their development partners to change the current situation. On the African side, governments must institute the necessary legal and regulatory frameworks to attract FDI and domestic investors in the natural resource development sector. ${ }^{31}$

On the other hand, external partners such as Qatar should invest more in a network of value-chain industrial enterprises in the natural resource sector, specializing in processing, value-addition and marketing of mineral-based products. Manufacturing provides opportunities for integration and value addition for both the agricultural and extractive sectors, and for the best use of the continent's comparative advantage that can help boost further export earnings and revenue generation. ${ }^{32}$

\subsection{Social Development}

A recent report from the ECA highlights that economic growth registered in Africa has not reduced poverty as expected in the light of underlying inequalities among social groups that continue to constrain equal opportunities and result in differentiated outcomes. The report further informs that "a one per cent increase in inequality increases poverty by 2.16 per cent in Africa, where gender inequality persists". ${ }^{33}$ Therefore, measures and commitment to ensure welfare outcomes such as income level, job security, personal health and social security protection for workers, especially women and the youth, will need to be put in place along industrial and agricultural value chains from national to global levels.

Countries will also need to ensure a match between demand and supply of labour skills. A new partnership with Qatar can offer lessons

30 ECA, Economic Report on Africa 2014: Dynamic Industrial Policy in Africa (Addis Ababa: UNECA and African Union Commission 2014).

31 UNECA. 2015. Economic Report on Africa 2015: Industrializing through Trade, (Addis Ababa: UNECA), Chapter 4 on Global Value Chains and Industrialization.

32 UNECA (n 2).

33 ECA. 2014. "Overview of Recent Economic and Social Developments in Africa. 
to African countries on how to go about developing their natural resource sector through value-addition and diversification, institute inclusive social policies in order to ensure the right of African citizens for basic health and education, and provide adequate and descent jobs to the growing African population that are under the age of 24 .

\section{GUIDING PRINCIPLES FOR A MUTUALLY BENEFICIAL QATAR-AFRICA PARTNERSHIP}

Genuine partnership entails much more than aid. It must include, in a holistic manner, the entire spectrum of economic, political, social and cultural relations between the cooperating parties. It also encompasses such values as trust and openness that are difficult to measure but which cannot be avoided if the relationship is to endure. ${ }^{34}$ The new Qatar-Africa partnership must be guided by the principles outlined below.

\subsection{Compatibility with African Aspirations}

The new Qatar-Africa partnership will be based on Africa's aspirations for structural transformation and inclusive and green growth, and will support its vision for economic diversification with enhanced productivity and value addition across economic sectors, that would result in sustainable employment and income gains. As past experience has shown, the development process cannot be sustainable if the partnership does not allow ample scope for African initiatives and aspirations to serve as the main organizing principles of the partnership.

\subsection{Transparency of Interests}

Partnerships work well when both parties place their interests squarely on the table right from the start. These should include not only expected benefits from the partnership, but also areas where the partners cannot see eye to eye or agree all the time. By being explicit from the beginning, the partners will be able to find a middle-ground without jeopardizing the opportunity to pursue long-term and beneficial economic relations between them.

34 H. Kifle, A Olukoshi, L Wohlgemuth, A New Partnership for African Development: Issues and Parameters (The Nordic Africa Institute, Uppsala 1997), pp. 12-13. 


\subsection{Alignment of Expectations}

The partnership will ensure alignment of expectations, mutual interests as well as competencies and capabilities from both sides at policy and strategic initiative levels, where socio-economic and political gains can be shared tangibly and equitably. The focus on productivity technology, market and investment opportunities addressing multi-dimensional demand from both sides will be crucial in ensuring a win-win partnership. It will also address the nexus between trade, foreign policy and development cooperation.

\subsection{Result-orientation}

Partnerships are not set in a vacuum; they must lead to tangible results or deliverables that validate the contribution of the partnership, as there always are with other partnerships, such as China. This is done through a monitoring and evaluation framework that sets benchmarks, targets and mechanisms to measure results. Such a framework also establishes that parties are mutually accountable for the progress made towards achieving the set objectives. ${ }^{35}$ This ensures mutual accountability. To take advantage of the new partnership, African countries must institute reforms, such as an enabling business environment, stamping out corruption, and reducing redtape.

\section{CONCLUSION}

Indeed, Qatar, more than any country in the Middle East, is better positioned to assume the role of an honest broker between African countries and foreign firms and governments wishing to invest in Africa's extractive sector. It can do so in several ways: offering alternative

35 The above principles derive from important frameworks each building on the previous to shift from aid effectiveness to effective development cooperation, including: (1) the Rome Declaration on harmonization in 2003; (2) the Paris Declaration with additional principles (ownership, alignment, managing for results and mutual accountability) in 2005; (3) the Accra Agenda for Action (AAA) in 2008, and its focus on civil society and parliament engagement, capacity development and enhanced role of recipient countries in determining the use of aid funds and untying aid; (4) the Bussan agenda in 2012 with focus on domestic resource mobilization, enhanced private sector engagement and fostering Private Public Partnerships; and (5) the Mexico agreement in 2013 with a special focus on development cooperation with fragile states. 
financing platform; building local capacity in resource extraction and value-addition; and by strengthening science and technology education. These activities will enable African countries to take a strategic approach to make the most out of natural resources through beneficiation, diversification and industrialization. ${ }^{36}$ To help African countries achieve these objectives, Qatar must consider the five measures discussed briefly in the following paragraphs.

The first is investment in the infrastructure sector to promote industrialization. A strong infrastructural base is critical to economic transformation, whether in agriculture or industry. The continent still lacks adequate infrastructure, including crucial linkages to markets such as collection centres, storage facilities, regular trucking facilities; roads, railways and ICT to support its growing economies, particularly in the rural areas. At present, transport costs in Africa are high compared to other regions. This is also true of the reliability of energy supply. It is estimated that over 60 per cent of people in sub-Saharan African will still not have access to electricity by 2020.Effective policy and investment in all forms of transport, communication, energy, and logistics are needed to increase competitiveness of industry and agriculture as well as boost trade.

The second is investment in technology, innovation, and research and development in the extractive sector. Technological advances and innovation are important determinants of competitiveness across economic sectors at the continental and global levels. Unfortunately, Africa still lags significantly behind other regions in science, technology and innovation. ${ }^{37}$ The continent's contribution to global knowledge production in the sciences is abysmal. In 2012, Africa accounted for about 0.8 per cent of the world total of about 2.35 million patent applications. Creating an enabling environment for innovation and technology transfer requires building a virtuous cycle between research centres/universities, industry and market that will provide rapid catchup opportunities. This would require forging strong partnerships with African institutions of higher learning to enhance technical skills, access to technology, product innovation, organizational and management processes, and marketing approaches to be able to compete in global markets.

36 UNECA (n 2).

37 UNECA. 2014. "Innovation and Technology Transfer for Enhanced Productivity and Competitiveness in Africa" (Background Paper 2014). 
Third is establishing an alternative financing platform for the extractive sector. Qatar can help break the BRICS financial hold on Africa by establishing an alternative financing platform for the extractive sector. There is a huge opportunity for private equity investors in sectors such as infrastructure and agriculture that has the potential to generate high return on investment. Qatar can lead the way on this.

Fourth is the need to build local capacity in resource extraction and value-addition. This involves public private partnership agreements to expand a network of medium and large value-chain enterprises exclusively focused on processing, value addition, and marketing of minerals and other extractive resources, including agricultural development and processing. This will open enormous opportunities for employment to large numbers of Africans while laying the foundation for the growth of indigenous extractive firms.

Fifth is the need to enhance the bargaining capacity of Africans through research, training and structured dialogue. To this end, it is necessary to establish, for instance at Hamad Bin Khalifa University Center for Natural Resource Governance aimed at providing short-term and long-term training to officials and legal experts from Africa in resource governance, bargaining and negotiation skills. The initiative requires close consultation with the Africa Union (AU) and the UN Economic Commission for Africa (ECA). This will be tailored to support the activities of the African Mineral Development Centre and the African Land Policy Initiative. The Centre will also be able to promote structured dialogue among African policy makers and the extractive industry by organizing high-level workshops and seminars. The key here is to balance inspirational goals and the reality on the ground. Capacity building should aim to bridge the gap and asymmetries between host countries and foreign investors (i.e., contract negotiation; licensing practices; transfer pricing, and so on).

It is clear from the foregoing analysis that a long-term and sustained economic development strategy in Africa will require a strategic approach in the development and management of Africa's natural resources. ${ }^{38}$ This will entail, on the part of African governments, the adoption of a fully integrated economic beneficiation strategy that deliberately encourages innovation and pays particular attention to

38 ECA and Emerging Markets Forum "Africa 2050: Realizing the Continent's Full Potential" (2009). 
the industries and services associated with inputs in the extractive sector (e.g. mining) as it has to do with post-mining processes and industrial use. A special focus should be directed at the enabling factors such as infrastructure development, rapid adoption of technology innovation, human capital development and institutional capacity building, in order to fully harness Africa's natural resources to achieve broad-based development and industrialization. ${ }^{39}$ Moreover, African governments must also ensure that Qatari investors build necessary infrastructure, and viable industrial capabilities with forward and backward linkages to promote internally articulated resource clusters and regional value chains.

39 In recent years, ECA's flagship report, Economic Report of Africa, have covered topics such as the role of the developmental state; unleashing Africa's potential as pole of global growth, making the most of African commodities; and the industrial policy imperatives for the continent. 